\title{
Lipid profile levels in HIV-AIDS patients on treatment with efavirenz and atazanavir. Cohort study
}

Fernando Geldres-Molina, ${ }^{1}$ Alex Castañeda-Sabogal, ${ }^{1}$ Maryori M. Hilario-Gómez ${ }^{2 *}$ and Joshuan J. Barboza ${ }^{3}$ ${ }^{1}$ Faculty of Medicine, Universidad Privada Antenor Orrego, Trujillo; ${ }^{2}$ Sociedad Científica San Fernando, Universidad Nacional Mayor de San Marcos, Lima; ${ }^{3}$ Universidad Señor de Sipán, Chiclayo, Peru

\begin{abstract}
Introduction: Antiretroviral treatment for HIV generates dyslipidemia, which is associated with cardiovascular risk and atherosclerosis. Objective: To compare antiretroviral agents effects on lipids in patients with HIV-AIDS. Methods: Retrospective cohort. The lipid profiles of patients receiving efavirenz (EFV) vs. atazanavir (ATV) with a zidovudine + lamivudine backbone for 36 months were compared. Results: 212 patients were included in the study. From baseline to month 36, HDL increase in the group of patients treated with ATV was higher in comparison with that of patients on EFV (8.33 vs. 4.26; $p<0.01$ ); a difference in triglycerides was observed between groups, with a decrease of $19.06 \mathrm{mg} / \mathrm{dL}$ in patients on ATV and an increase of $40.62 \mathrm{mg} / \mathrm{dL}$ in those who received EFV $(p<0.001)$. Mean difference in total and LDL-cholesterol change between both treatments was not significant ( $p=0.32$ and $p=0.951$, respectively). Conclusions: ATV-containing regimens were associated with more favorable changes in triglyceride and HDL levels than EFV regimens. This benefit could be associated with a reduction in long-term cardiovascular risk; this relationship requires further study.
\end{abstract}

KEY WORDS: Antiretroviral agents. Efavirenz. Atazanavir sulfate. HIV. Lipid profile.

\section{Niveles de perfil lipídico en pacientes con VIH-sida en tratamiento con efavirenz y atazanavir. Estudio de cohorte}

\section{Resumen}

Introducción: El tratamiento antirretroviral para VIH genera dislipidemia asociada a riesgo cardiovascular y aterosclerosis. Objetivo: Comparar los efectos lipídicos de los antirretrovirales en pacientes con VIH-sida. Métodos: Cohorte retrospectiva. Se comparó el perfil lipídico de los pacientes que recibieron efavirenz (EFV) versus atazanavir (ATV) con una backbone de zidovudina + lamivudina durante 36 meses. Resultados: Se incluyeron 212 pacientes. Desde el inicio hasta los 36 meses, el aumento del HDL del grupo de pacientes en tratamiento con ATV fue mayor en comparación con el que presentaron los pacientes con EFV (8.33 versus 4.26, respectivamente; $p<0.01$ ); se observó una diferencia de triglicéridos entre los grupos, con disminución de $19.06 \mathrm{mg} / \mathrm{dL}$ en los pacientes con ATV y aumento de $40.62 \mathrm{mg} / \mathrm{dL}$ en los que recibieron EFV $(p<0.001)$. La diferencia de medias en el cambio de colesterol total y LDL entre ambos tratamientos no fue significativa $(p=0.32$ y $p=0.951$, respectivamente). Conclusiones: Los regímenes con ATV se asociaron a cambios más favorables en los niveles de triglicéridos y HDL que los regímenes con EFV, relación que podría asociarse a reducción del riesgo cardiovascular a largo plazo, la cuál requiere estudios adicionales.

PALABRAS CLAVE: Agentes antirretrovirales. Efavirenz. Sulfato de atazanavir. VIH. Perfil lipídico.

Correspondence:

*Maryori M. Hilario-Gómez

E-mail: maryorimhg010514@gmail.com
Gac Med Mex. 2021;157:384-390

Contents available at PubMed

www.gacetamedicademexico.com

0016-3813/@ 2021 Academia Nacional de Medicina de México, A.C.. Published by Permanyer. This is an open access article under the CC BY-NC-ND license (http://creativecommons.org/licenses/by-nc-nd/4.0/). 


\section{Introduction}

HIV/AIDS is one of the most destructive diseases for humanity. ${ }^{1}$ Currently used drugs are associated with adverse effects, including dyslipidemia, which is associated with the development of atherosclerosis; ; in addition, antiretroviral drugs increase oxidative stress, which promotes cardiovascular disease, with all subsequent consequences, including death. ${ }^{3}$

The success of antiretroviral drugs could be obscured by their impact on long-term lipid profile. There are no clear conclusions regarding the differences of different antiretroviral drugs effects on lipids. ${ }^{4,5}$ Given that in Peru there are no publications on this subject, and that few specifically compare efavirenz (EFV) and atazanavir (ATV), this investigation seeks to compare them in association with zidovudine and lamivudine (3TC) with regard to the changes they produce in the lipid profile over a 36-month period.

\section{Methods}

A retrospective cohort study was conducted to compare the lipid profile of patients receiving EFV vs. ATV with a backbone combination of two nucleoside inhibitors, zidovudine and lamivudine, for a period of 36 months. ATV was the standard rescue treatment of choice during the years the study information was collected, recommended in national guidelines from 2005 to $2015 .^{6,7}$ Currently, it continues to be used in patients who received ATV in previous years.

Patients who participated in the STD/HIV-AIDS prevention and control program at "Víctor Lazarte Echegaray" Hospital, in Trujillo, Peru, and who received antiretroviral treatment during the 2005-2016 period, were older 18 than years of age, from either gender, had baseline control measurements (prior to treatment initiation), had at least six continuous six-monthly control measurements, and who had maintained the assigned treatment regimen constantly and regularly, at least during the study period, were selected.

A census sampling was used, in which 352 patients who received an antiretroviral regimen participated. The cohort consisted of two groups. Participants in the first group were patients older than 18 years who started treatment with EFV in combination with zidovudine and lamivudine and had lipid profile records for all three years of treatment. Participants in the second group had the same characteristics, only with EFV being replaced by ATV. Patients with stage 3 or higher chronic kidney disease, type 1 or 2 diabetes mellitus, obesity, and treatment with lipid-lowering drugs for more than 6 months were excluded. During the years of data collection, HIV viral load or CD4 count was not available at the hospital. Selected patients did not have opportunistic infections or conditions indicative of AIDS stage since their inclusion in the cohort or during the study period.

The lipid profile was measured prior to treatment initiation, as well as at 12, 24, and 36 months of follow-up. Hypercholesterolemia, hypertriglyceridemia, and decreased HDL-cholesterol were regarded as dyslipidemias. ${ }^{8}$

Data were collected from medical records and laboratory test results registered at hospital management system.

Patient databases were reviewed, the type of treatment patients received was verified and groups that were to receive EFV and ATV were formed. Subsequently, the information was consolidated in a spreadsheet on the SPSS program, version 21, for the corresponding statistical analysis.

Qualitative variables were reported as frequencies and percentages. For quantitative variables, given that the sample was limited and had a non-normal distribution according to Kolmogorov-Smirnov non-parametric test, the mean and standard deviation were calculated. Student's t-test was used for related samples in order to determine the time at which changes occurred for each lipid profile component and the difference between baseline and last measurement. In addition, paired samples t-test served to compare the changes that occurred in lipid profile components between both treatment regimens. A $p$-value $<0.05$ was considered to be statistically significant.

Confidentiality of each patient's information was ensured, for which only codes were assigned to each interview, with informed consent previously being obtained. The study was approved by the hospital research and ethics committee.

\section{Results}

Of a total of 352 patients, only 212 met the inclusion criteria. There were 135 patients in the EFV-treated group, out of whom 54 were excluded. On the other hand, 77 patients were obtained for the ATV-treated group with, out of whom eight were excluded (Fig. 1). 


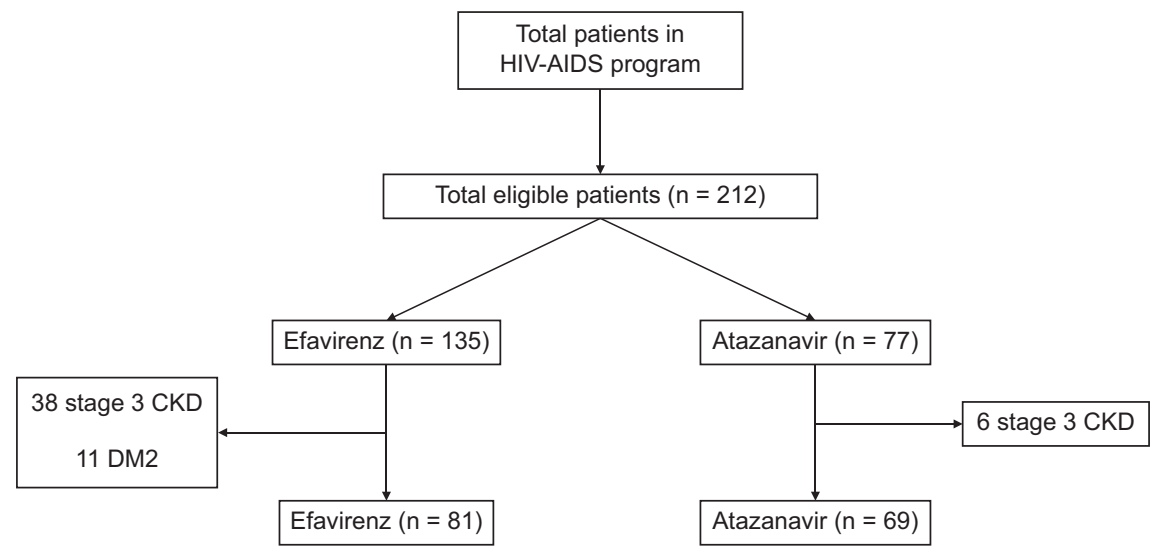

Figure 1. Sample population selection according to inclusion and exclusion criteria.

CKD: chronic kidney disease; DM: diabetes mellitus.

Table1. Clinical and epidemiological characteristics of patients with HIVIAIDS

\begin{tabular}{|c|c|c|c|c|c|c|c|c|c|c|c|c|}
\hline \multirow[t]{3}{*}{ Parameter } & \multicolumn{12}{|c|}{ Lipid proffle } \\
\hline & \multicolumn{3}{|c|}{ Baseline average } & \multicolumn{3}{|c|}{ Average at 12 months } & \multicolumn{3}{|c|}{ Average at 24 months } & \multicolumn{3}{|c|}{ Average at 36 months } \\
\hline & $\begin{array}{c}\text { EFV } \\
(n=81)\end{array}$ & $\begin{array}{c}\text { ATV } \\
(n=69)\end{array}$ & $p$-value & $\begin{array}{c}\text { EFV } \\
(n=81)\end{array}$ & $\begin{array}{c}\text { ATV } \\
(n=69)\end{array}$ & p-value & $\begin{array}{c}\text { EFV } \\
(n=81)\end{array}$ & $\begin{array}{c}\text { ATV } \\
(n=69)\end{array}$ & p-value & $\begin{array}{c}\text { EFV } \\
(n=81)\end{array}$ & $\begin{array}{c}\text { ATV } \\
(n=69)\end{array}$ & p-value \\
\hline $\begin{array}{l}\text { Total cholesterol* } \\
(\mathrm{mg} / \mathrm{dL})\end{array}$ & 195.77 & 180.37 & 0.000 & 193.59 & 182.50 & 0.018 & 200.37 & 189.86 & 0.036 & 208.33 & 189.11 & 0.000 \\
\hline $\begin{array}{l}\text { LDL-cholesterol* } \\
(\mathrm{mg} / \mathrm{dL})\end{array}$ & 107.60 & 96.17 & 0.046 & 103.97 & 95.98 & 0.109 & 106.86 & 97.75 & 0.074 & 110.37 & 98.73 & 0.023 \\
\hline $\begin{array}{l}\text { HDL-cholesterol* } \\
(\mathrm{mg} / \mathrm{dL})\end{array}$ & 41.45 & 37.71 & 0.073 & 42.95 & 41.75 & 0.677 & 43.13 & 43.02 & 0.945 & 45.77 & 46.04 & 0.894 \\
\hline $\begin{array}{l}\text { Triglycerides* } \\
\mathrm{mg} / \mathrm{dL} \text { ) }\end{array}$ & 163.23 & 200.52 & 0.027 & 168.16 & 187.28 & 0.125 & 180.87 & 180.08 & 0.961 & 186.69 & 173.40 & 0.199 \\
\hline
\end{tabular}

*Mean obtained with independent samples t-test. Student's t-test for independent samples.

LDL: low-density lipoprotein; HDL: high-density lipoprotein; EFV: efavirenz; ATZ: atazanavir. Student's t-test for independent samples was carried out.

Overall patient mean age was $39.97 \pm 10.92$ years. No significant differences were found between the EFV and ATV groups with regard to age (39.11 \pm 10.89 vs. $40.99 \pm 10.73)$ and gender (56\% vs. $44 \%)$ (Table 1).

Table 2 shows total cholesterol, LDL-cholesterol, HDL-cholesterol and triglycerides average baseline values in the groups that received treatment with EFV and ATV. Baseline total and LDL-cholesterol levels were significantly higher in EFV-treated patients in comparison with ATV-treated patients $(p<0.05)$. Triglyceride values were substantially higher in ATV-treated patients than in those treated with EFV $(p<0.05)$.

As for total cholesterol, in patients who received ATV, it showed a significant change at 24 months $(+9.49 \mathrm{mg} /$
$\mathrm{dL} ; \mathrm{p}<0.01$ ), while in patients with EFV the increase was significant only at 36 months $(+12.56 \mathrm{mg} / \mathrm{dL}$; $p<0.01)$. LDL-cholesterol values did not show significant changes during the observation period in either treatment group.

Regarding HDL-cholesterol values, the EFV-treated group showed a significant increase of $1.68 \mathrm{mg} / \mathrm{dL}$ at 24 months $(p<0.01)$, while a significant increase of $4.04 \mathrm{mg} / \mathrm{dL}(p<0.01)$ was observed at 12 months in the ATV group. In addition, regarding triglyceride values, EFV-treated patients had a significant increase at 12 months $(+4.93 \mathrm{mg} / \mathrm{dL} ; p<0.01)$. In contrast, patients in the ATV group showed a significant decrease at 24 months (-11.94 mg/dL; $p<0.05)$ (Fig. 2).

Finally, a comparison was made of the changes in mean lipid profile at 36 months in both groups. The 
Table 2. Average lipid profile at baseline, at 36 months and change throughout the observation period

\begin{tabular}{|c|c|c|c|c|}
\hline Variables & $\begin{array}{l}\text { Total population } \\
\qquad n=150\end{array}$ & $\begin{array}{c}E F V \\
n=81(54 \%)\end{array}$ & $\begin{array}{c}\text { ATV } \\
n=69(46 \%)\end{array}$ & p-value \\
\hline$>40$ years & 73 & $37(50)$ & $36(50)$ & \multirow[t]{2}{*}{0.428} \\
\hline$<40$ years & 77 & $44(57.3)$ & $33(42.7)$ & \\
\hline Male gender & 116 & $65(56.0)$ & $51(44.0)$ & \multirow[t]{2}{*}{0.35} \\
\hline Female gender & 34 & $16(47.0)$ & $18(53.0)$ & \\
\hline Latin origin & 150 & $81(54)$ & $69(46)$ & \\
\hline Age, years (mean $\pm S D)$ & $39.97 \pm 10.92$ & $39.11 \pm 10.89$ & $40.99 \pm 10.73$ & 0.292 \\
\hline
\end{tabular}
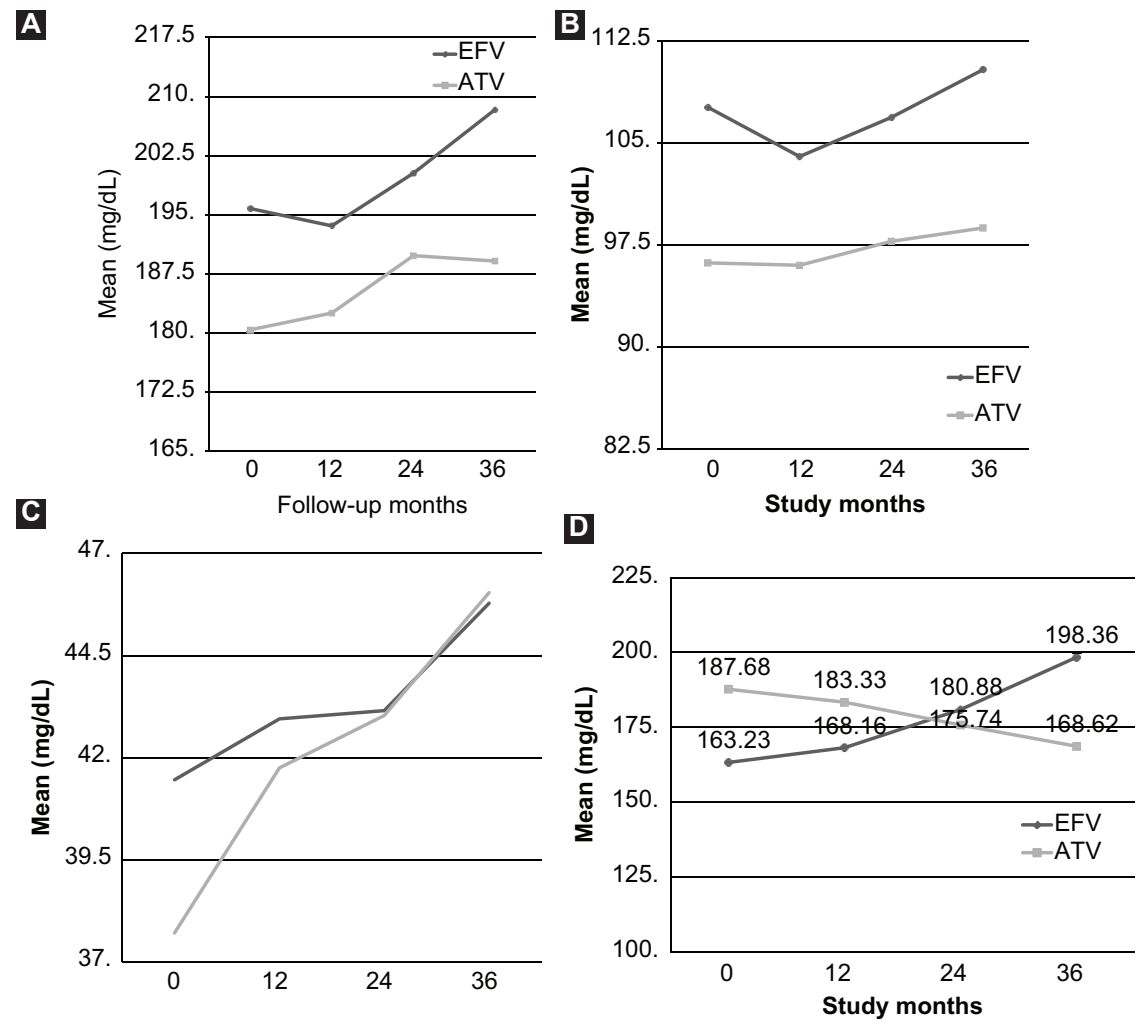

Figure 2. (A) Total cholesterol during the entire study period with efavirenz vs. atazanavir. (B) LDL-cholesterol throughout the study period. (C) HDL-cholesterol. (D) Triglycerides.

increase from mean baseline HDL-cholesterol values at 36 months was larger in the group treated with ATV in comparison with EFV-treated patients $(p<0.01)$. No significant values were found in mean differences at 36 months for total and LDL-cholesterol in the groups treated with EFV and ATV. Regarding mean triglycerides at 36 months in the EFV group, there was a mean increase of 4.62 , while in the group with ATV there was a mean reduction of $19.06(p<0.001)$ (Fig. 3).

\section{Discussion}

Our findings suggest that ATV-containing antiretroviral regimens do not produce significant alterations in the lipid profile in comparison with EFV.

In patients with HIV, the use of some antiretroviral agents, especially protease inhibitors, has entailed the development of endothelial, mitochondrial and cellular dysfunctions, as well as an increase in tumor 


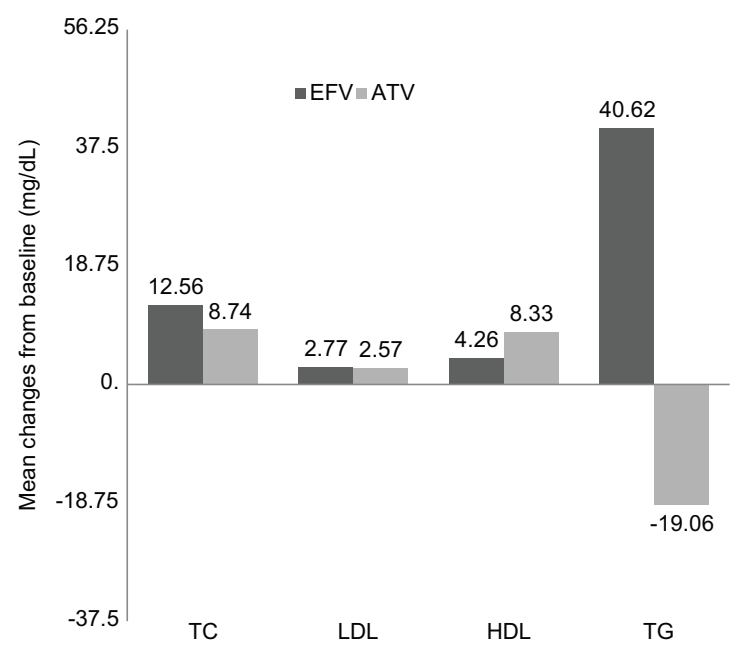

Figure 3. Triglycerides during the period of study with efavirenz vs. atazanavir. Paired samples t-test was used.

necrosis factor- $\alpha$ and interleukins 1 and 6 , which further favor lipogenic state. ${ }^{9}$ Dyslipidemia is a long-term complication related to a significant increase in cardiovascular events-associated mortality rate.

The incidence of dyslipidemia in our series was similar to that found in another study carried out in Peru, where Rondán et al. found a prevalence of $74.7 \% .^{10}$ Furthermore, in an analysis that included more than 4000 patients from seven Latin American countries, overall dyslipidemia was $80.2 \%$, with $67.9 \%$ of dyslipidemia being found in Peruvian patients. ${ }^{10,11}$

Patients who received ATV had a favorable decrease in triglycerides after 12 months of treatment, which was evident at 36 months. HDL-cholesterol had an increase that started at 12 months of treatment and went on increasing toward the final observation period. These results are comparable with those of the study carried out by Carey et al., who used ATV with an AZT + 3TC backbone, which produced favorable changes in HDL-cholesterol. Patients in the referred study used ATV alone or with ritonavir; the latter was shown not to influence LDL-, HDL-cholesterol or triglyceride levels. ${ }^{2}$

Our analysis indicated that, after 36 months of treatment, patients with ATV had more favorable changes in lipid profile, which translates into an essential benefit with regard to triglycerides and HDL-cholesterol. Both groups showed an increase in total cholesterol, which was higher in the group with EFV $(+12.56 \mathrm{mg} / \mathrm{dL}$ vs. $8.33 \mathrm{mg} / \mathrm{dL}$ ), but the difference was not statistically significant. On the other hand, no significant changes in LDL-cholesterol were found in either group.
As for triglycerides, our results agree with those obtained by Squires et al., who in a double-blind randomized trial with 810 patients found a $9 \%$ reduction in triglycerides in favor of ATV with the same backbone we used:13 on the other hand, Daar et al., in a randomized study of 685 patients, compared EFV and ATV using tenofovir, emtricitabine and abacavir-lamivudine as backbone; they found no significant differences in triglycerides. ${ }^{14}$

We identified that both EFV and ATV produce this important beneficial change in HDL-cholesterol, with some advantage for the group that received the latter.

The relationship of highly active antiretroviral therapy with a low HDL-cholesterol and high triglyceride pattern is known, as indicated by Estrada and PortiIla,${ }^{15}$ which is called "atherogenic dyslipidemia;" among these changes, low HDL-cholesterol levels ( $<35 \mathrm{mg} / \mathrm{dL}$ ) are directly related to mortality from cardiovascular disease $(\mathrm{OR}=22.92 ; \mathrm{p}=0.03)$ in patients with HIV. ${ }^{16}$ A reduction of up to $60 \%$ in cardiovascular risk has been recorded in patients who receive ATV. ${ }^{17}$ The relationship between the use of ATV and a beneficial effect on carotid intima-media thickness is another piece of information in favor of its good cardiovascular profile. $^{18}$

The results obtained by Estrada et al. regarding the fact that pro-inflammatory and oxidative state (measured by phospholipase A2 and myeloperoxidase serum concentrations) is lower in patients with regimens based on ATV in comparison with $\mathrm{EFV},{ }^{19}$ might also explain the clinical benefit in the lipid profile observed with ATV.

The main strength of this study was the 36-month patient follow-up, which had as primary goal evaluating changes in the lipid profile, unlike most previous investigations that addressed the lipid profile as a secondary outcome. Given that dyslipidemia etiopathogenesis in HIV is multifactorial and is also associated with ethnic, socioeconomic and cultural factors, this study is highly important because it is the first of this type to be carried out in our country. ${ }^{20}$

One limitation of the present analysis is that the atherogenic phenomenon can be expressed at different moments depending on patient genetics. Although another important limitation was not having viral load and CD4 count data, Kelesidis et al. observed that the use of protease inhibitors was associated with dyslipidemia, regardless of viral load, CD4 lymphocyte count, gender, and even other cardiovascular 
risk factors such as smoking; ${ }^{21}$ hence, clinical outcome would remain as a surrogate pattern with this evidence. Therefore, in the present study, the interpretation of laboratory parameters follow-up results (lipid profile) had to be carried out exclusively in the context of exposure to two different classes of antiretroviral drugs, since the main axis of the regimen was the same in both groups (zidovudine/lamivudine). In the medical records of the patients included in this study, no allusion to the use of lipid-lowering drugs was found, and corroborating with a subsequent survey if the patients received these drugs was not possible.

Dyslipidemia severity varies depending on the employed regimen. For this reason, the use of protease inhibitors is already included as a factor in some cardiovascular risk scales..$^{22}$ In this study, one of the comparators was used as a protease inhibitor, ATV, but the cases selected for analysis were those where it was not used together with ritonavir. In contrast to the above, Rondón's analysis recorded a strong association between dyslipidemia and the use of protease inhibitors, but the protease inhibitors that were used were lopinavir/ritonavir, ATV and ritonavir. Therefore, the United States Department of Health and Human Services ${ }^{23}$ expert panel points out that all ritonavir-boosted protease inhibitors increase HDL- and LDL-cholesterol levels, as well as triglycerides, which explains the difference with other series that did not compare the levels of cholesterol and triglycerides with ATV not boosted with ritonavir, as it was done in this study.

\section{Conclusions}

This research has shown that non-boosted ATV produced more favorable lipid changes than EFV in the study population, which could be associated with a long-term decrease in cardiovascular risk.

\section{Funding}

This research did not receive any specific grant from agencies of the public, commercial or non-profit sectors.

\section{Conflict of interests}

The authors declare that they have no conflicts of interest.

\section{Ethical disclosures}

Protection of human and animal subjects. The authors declare that no experiments were performed on humans or animals for this research.

Confidentiality of data. The authors declare that they followed the protocols of their work center on the publication of patient data.

Right to privacy and informed consent. The authors obtained informed consent from the patients or subjects referred to in the article. This document is in the possession of the corresponding author.

\section{References}

1. Sárcamo CC, Blitchtein-Winicki D, Valverde RA, Best RJ, Suárez-Ognio L, Campos GJ, et al. Estudio basal de prevalencia de sífilis y VIH y comportamientos asociados en población privada de libertad, Perú 1999. Rev Peru Med Exp Salud Publica. 2003;20:9-14.

2. Rodríguez-Vidigal FF, Muñoz-Sanz A. Alteraciones del metabolismo de los lípidos en los pacientes infectados por el virus de la inmunodeficiencia humana. Una hipótesis acerca de su patogenia. Med Clin. 2000;115:145-50.

3. Roca B. Trastornos metabólicos relacionados con el VIH y el tratamiento antirretroviral. An Med Interna (Madrid). 2003:20:37-45.

4. Guevara FO, Cañón B, Liévano MC, Lombo B, Rendón I, Blanco F. Prevalence of metabolic syndrome in patients infected with HIV. Acta Med Colombiana. 2008:33:7.

5. Ministerio de Salud. Norma Técnica de Salud de Atención Integral del Adulto con Infección por el Virus. Peru: Ministerio de Salud; 2018.

6. Geldres-Molina F. Niveles de Perfil Lipídico en Pacientes con VIH-SIDA en Tratamiento con Efavirenz y Atazanavir. EsSalud. La Libertad. 20052016. Peru: Universidad Privada Antenor Orrego; 2017.

7. Ministerio de Salud. Norma Técnica de Salud de Atención Integral del Adulto con Infección por el Virus de la Inmunodeficiencia Humana. Peru: Ministerio de Salud; 2015.

8. Pallarés-Carratalá V, Pascual-Fuster V, Godoy-Rocatí D. Dislipidemia y riesgo vascular. Una revisión basada en nuevas evidencias. Semergen. 2015;41:435-45.

9. Pacífico J, Gutiérrez C. Información sobre la medicación y adherencia al tratamiento antirretroviral de gran actividad en pacientes con $\mathrm{VIH} /$ sida de un hospital de Lima, Perú. Rev Peru Med Exp. 2015;32:66-72.

10. Rondán PL, Flores-Flores O, Doria NA, Valencia-Mesías G, Chávez-Pérez V, Soria J. Elevada frecuencia de dislipidemia en pacientes infectados por VIH en un hospital público peruano. Rev Peru Med Exp. 2017;34:239-44.

11. Cahn P, Leite O, Rosales A, Cabello R, Álvarez CA, Seas C, et al. Metabolic profile and cardiovascular risk factors among Latin American HIV-infected patients receiving HAART. Braz J Infect Dis. 2010;14:158-66.

12. Carey D, Amin J, Boyd M, Petoumenos K, Emery S. Lipid profiles in HIV-infected adults receiving atazanavir and atazanavir/ritonavir: systematic review and meta-analysis of randomized controlled trials. J Antimicrob Chemother. 2010;65:1878-88.

13. Squires KE, Young B, Dejesus E, Bellos N, Murphy D, Zhao HH, et al. Similar efficacy and tolerability of atazanavir compared with atazanavir/ ritonavir, each with abacavir/lamivudine after initial suppression with abacavir/lamivudine plus ritonavir-boosted atazanavir in HIV-infected patients. AIDS. 2010;24:2019-27.

14. Daar ES, Tierney C, Fischl MA, Sax PE, Mollan K, Budhathoki C, et al. Atazanavir plus ritonavir or efavirenz as part of a 3-drug regimen for initial treatment of HIV-1. Ann Intern Med. 2011:154:445-56.

15. Estrada V, Portilla J. Dyslipidemia related to antiretroviral therapy. AIDS Rev. 2011;13:49-56.

16. Jain N, Tripathi AK, Vaish AK, Verma SP, Himanshu D, Gutch M. Can metabolic factors be used prognostically for short-term mortality in HIV-infected patients? Ann Med Health Sci Res. 2012;2:124-8.

17. Díaz CM, Segura ER, Luz PM, Clark JL, Ribeiro SR, De Boni R, et al. Traditional and HIV-specific risk factors for cardiovascular morbidity and mortality among HIV-infected adults in Brazil: a retrospective cohort study. BMC Infect Dis. 2016;16:376.

18. Chow D, Shikuma C, Ritchings C, Guo M, Rosenblatt L. Atazanavir and cardiovascular risk among human immunodeficiency virus-infected patients: a systematic review. Infect Dis Ther. 2016;5:473-89. 
19. Estrada V, Monge S, Gómez-Garre D, Sobrino P, Berenguer J, Bernardino $\mathrm{Jl}$, et al. Comparison of oxidative stress markers in HIV-infected patients on efavirenz or atazanavir/ritonavir-based therapy. J Int AIDS Soc. 2014;17:19544.

20. Pozniak AL, Gallant JE, DeJesus E, Arribas JR, Gazzard B, Campo RE, et al. Tenofovir disoproxil fumarate, emtricitabine, and efavirenz versus fixed-dose zidovudine/lamivudine and efavirenz in antiretroviral-naive patients: virologic, immunologic, and morphologic changes--a 96-week analysis. J Acquir Immune Defic Syndr. 2006;43:535-40.
21. Kelesidis T, Currier JS. Dyslipidemia and cardiovascular risk in human immunodeficiency virus infection. Endocrinol Metab Clin North Am. 2014;43:665-84.

22. Friis-Møller N, Ryom L, Smith C, Weber R, Reiss $P$, Dabis F, et al. An updated prediction model of the global risk of cardiovascular disease in HIV-positive persons: The data-collection on adverse effects of anti-HIV drugs (D: A:D) study. Eur J Prev Cardiol. 2016;23:214-23.

23. NIH. What's New Adult and Adolescent Opportunistic Infection. AIDSinfo; 2019. 